\title{
Confucius the Chameleon: Dubious Envoy for "Brand China"
}

\section{Kam Louie}

At the end of his 1995 article "Confucius in the Borderlands: Global Capitalism and the Reinvention of Confucianism," Arif Dirlik remarks, "The discourse on Confucianism in the eighties made Confucius into an Oriental 'money-bag'; one article lauding the functionality of Confucianism to money-making is entitled, appropriately enough, 'The Cash Value of Confucian Values.' The most recent revival of Confucianism may indeed be a sign of its final demise."1 Fifteen years later, it appears that Dirlik's prediction of the decline of Confucianism was premature. In the twenty-first century, Confucianism continues to evolve inexorably and spread apparently unchecked around the globe. Confucianism is a remarkably pliable ideology, and Confucius has proved to be an extremely alluring "pinup boy." Indeed, not only is Confucianism thriving in the twenty-first century; it is likely to become even more influential in the foreseeable future. China's recent economic and political rise has produced a concomitant surge in

Unless otherwise noted, all translations are my own.

1. Arif Dirlik, "Confucius in the Borderlands: Global Capitalism and the Reinvention of Confucianism," boundary 2 22, no. 3 (Fall 1995): 273.

boundary $238: 1$ (2011) DOI 10.1215/01903659-1262554 @ 2011 by Duke University Press 
interest in "Chinese" culture. Into this discursive space, the government of the People's Republic of China (PRC) has offered Confucianism to domestic and international audiences hankering to locate "China's uniqueness" as the key emblem of Chinese culture and the paramount symbol of Chinese civilization. Confucius and Confucianism have become China's "brand" in a world where national identity is marketed for political spin.

\section{What's in a Name? Confucius by Any Other ...}

Political leaders who have grand, global aspirations, like the PRC's current rulers, want their particular culture to have an international impact. Confucius, newly wrested from the arms of other East Asian politicians and business leaders and their "Asian values" initiative of the 1980s, has become a twenty-first-century diplomat to facilitate PRC "soft power." In the first decade of the new millennium, the PRC government, through its educational wing, established a series of Confucius Institutes as part of its "soft power" project. The first of these institutes appeared in November 2004, and although the initial plan was to establish 100, by the end of 2007 there were already 210 Confucius Institutes in place globally. ${ }^{2}$ By 2009, there were more than 300. In the name of Confucius, the PRC government now has a cultural wing akin to Italy's Dante Alighieri Society and Germany's Goethe Institute.

However, unlike Dante and Goethe, the name Confucius has been at the center of some of the most savage intellectual and political controversies in modern China. The meaning of Confucius and Confucianism has also undergone major transformations over time. I begin this essay with a discussion of the Confucius Institutes because they are concrete manifestations of how China is attempting to assert itself globally as part of its "soft power" policy. At the same time, their establishment reveals the nation's current understanding of itself as a cultural entity. The many, and radically different, representations of Confucius reveal the psychological condition of China at large: a one-party state that is desperately trying to find a solution to its "crisis of faith," and in doing so is beset by an inconsistent and contradictory ideological apparatus. Confucius as "brand China" may be an accurate reflection of an ideologically confused country. But because the global influence of China is likely to become increasingly more pronounced,

2. Yiwei Wang, "Public Diplomacy and the Rise of Chinese Soft Power," Annals of the American Academy of Political and Social Science 616 (March 2008): 265. 
I argue that it is irresponsible to export such a schizophrenic persona as China's contribution to world culture.

Furthermore, unlike their European counterparts, the Confucius Institutes operate in conjunction with universities, in a joint-venture structure. The institutes leverage the host university's educational credentials to deliver Chinese language and culture courses to a broad public. Such a move implicates the cultural commitment of the host countries in their appreciation of what is Chinese culture, even though culture is meant to be only a secondary consideration of these initiatives. The constitution and bylaws of the Confucius Institutes and the pronouncements of the bureaucrats and managers of the institutes themselves state that their goal is primarily to enhance learning the Chinese language in foreign countries and, to a lesser extent, to expand knowledge of Chinese culture. ${ }^{3}$ Officials in the government department responsible for the Confucius Institutes program, the Hanban, insist that the institutes do not seek to promote any particular values; rather, they aim to enhance knowledge of Chinese language and culture. ${ }^{4}$ In other words, although these institutes are named after Confucius, their goal is not to spread Confucianism around the world. The "Confucius" in their title is merely a recognizable brand name that signifies Chinese culture, just as Goethe marks German culture.

Such protestations only underline the fact that naming is never a benign process - names matter, and they matter particularly within a Confucian rubric. The choice of Confucius as the icon of Chinese culture indicates the direction that the Chinese government wants to take. Ostensibly, China's search for wealth and power is based on moderation, harmony, and humane governance-qualities that the current advocates of Confucianism presume Confucius himself preached some two thousand years ago. This assumption may be true, but as the following summary of the trajectory and transformations of Confucius and The Analects over the last century shows, the Confucius icon has been used to represent such radically different views that the only way to reconcile these differences is to either embrace a self-contradictory philosophy or denounce generations of interpreters as hypocrites or misguided fools.

All fundamentalists or iconoclasts make absolute claims about canons and gospels that they seek to uphold or destroy. This essay is not

3. Details about the constitution and members of council are listed on the official website of the Confucius Institutes, http://college.chinese.cn/en/.

4. Ni Yanshuo, "Confucius Around the World," Beijing Review 51 (March 6, 2008): 26-27. 
an attempt to prove or disprove the claims made by those who defend or oppose Confucianism. I will show that because Confucius has in the last sixty years come to stand for practically anything, it has enabled academics and politicians to advance a set of "core Confucian values" for the contemporary world that is at best highly conservative and at worst schizophrenic. In China, pronouncements made by public intellectuals are often initiated by and later reinforced by politicians, and have very significant consequences. Furthermore, because of China's growing international prominence, these meditations by philosophers are no longer simply an internal Chinese affair. They have become a global and multinational business. Their goal of unearthing an original Confucianism that is compatible with international best practice is part of the search for an "Asian value" that can fill the perceived moral vacuum in the world today. In this essay, I will explore the implications of such a global Confucius, exemplified by the establishment and naming of the Confucius Institutes.

\section{Exhuming the Kong Family Shop and Flogging Back to Life a Dead Kongzi}

The left-wing activists who inherited the iconoclasm of May Fourth did such a thorough job of "smashing" the old ideas represented by the "Confucius Shop" that, by the time they took control of China in 1949, Confucius, representing "feudal culture," was officially dead. Some were happy with the prospect of an indigenous pattern of thought being replaced by a foreign ideology, Marxism. But others were not. As I have shown elsewhere, ${ }^{5}$ influential intellectuals made a concerted effort to incorporate traditional Chinese culture into the new China. Mao Zedong's comment that China should inherit the best of Chinese tradition from Confucius to Sun Yat-sen was repeated ad nauseam to justify the continuation of traditional ideas and practices. Given the restrictions imposed on academic debate in those days, these justifications were based on the argument that the core essence of Confucius's teachings was positive and compatible with Communism.

The best example of such an argument was advanced by the neoConfucian philosopher Feng Youlan. Feng Youlan was based at Peking University and was one of the most influential thinkers in China even

5. Kam Louie, Critiques of Confucius in Contemporary China (Hong Kong: Chinese University Press, 1980). 
before 1949. He devised what he called the "abstract inheritance method" to ensure that the essential features of Confucianism were preserved in China. Feng Youlan claimed that there were some general principles of traditional thought (the "abstract principles") that might have been created in feudal times, but whose essences were applicable to the new socialist society. This way of "abstracting" essential features of complex and often inconsistent modes of thinking is similar to some of the arguments put forward in the late 1980s by those who claimed that there were some universal ingredients in the various Asian cultures that constituted, and should be treasured as, "Asian values."

However, in terms of actual scholarly assessments of Confucius and his teachings, even though Feng Youlan and his supporters continued to write in this vein until the early 1970s, what they said was not particularly new. They mostly continued to reiterate the interpretations that they had made decades earlier. In fact, in terms of innovative ways of reading old texts, the most interesting examples in the 1950s and 1960s were made, unsurprisingly, by a younger generation of scholars trained in Marxist methodology, who uncompromisingly used class as a primary tool for analyzing Chinese traditions. They did this systematically for all texts. Indeed, they adhered so strictly to their mechanistic way of employing class analysis that, while they did bring a refreshing approach to traditional Chinese philosophy, theirs quickly became an inflexible orthodoxy that served the fanaticism of the Cultural Revolution. A couple of well-known examples will serve to illustrate their method.

By tracing the etymology of key words in The Analects and reinterpretations of pre-Qin history, these younger historians and philosophers asserted that Confucian ideas were created as ideological weapons by the slave-owning class in the Spring and Autumn Period and Warring States Period to oppress the people - the slaves - and to stop historical progress. For example, one of the basic virtues in The Analects is ren (仁), and interpretations of this concept have been central to how Confucianism has been assessed. Traditional scholarship tended to interpret ren as "benevolence emanating from a sagely gentleman in his dealings with others"; some modern scholars claim that ren is proof that Confucius had discovered a common humanity in man. However, radical Marxists such as Zhao Jibin, through an examination of textual evidence, argued that ren was used only in conjunction with the elite. One definition of ren given in The Analects is ai ren (爱人) - "love the people." Zhao Jibin shows that this does not simply translate as "love the people"; indeed, such a rendition is misleading. 
Ren (人) was always used in The Analects to refer to the upper classes, not the ordinary people. The notion of love and benevolence never extended to the common people, because a different word altogether-min (民) - was used in The Analects to refer to "the common people." And ren (仁) was never associated with min. Controlling words, such as shi (使), were used in conjunction with $\min$. So Confucius was said to have been interested only in how to "use" people, never in loving them.

By claiming that Confucius worked only on behalf of the slaveowning class, and that therefore the benevolence he preached was intended only for the ruling classes, historians were able to assert that Confucius opposed anything that offered the prospect of better conditions for the majority of people. Needless to say, such analyses fundamentally changed the way in which the classics were viewed, but during the 1950s and early 1960s these discussions remained in the academic sphere. And while they were quite revolutionary, their tone also remained measured and scholarly compared to the passionate outburst against tradition during the May Fourth movement, with its slogan, "Down with the Confucius Shop." In fact, the May Fourth voices were among the "Hundred Schools" of thought that were allowed to contend. However, by the time of the Cultural Revolution, especially during the anti-Confucius campaign of the early 1970s, the theses advanced by such younger scholars as Zhao Jibin, Yang Rongguo, and Guan Feng were the only ones permitted and officially promoted.

In hindsight, we now know that the nationwide "Criticize Lin Piao and Confucius" (piLin piKong) campaign of the early 1970s was a last desperate attempt by the so-called Gang of Four to launch a political offensive to enable them to stay in power when they knew that their patron, Mao Zedong, was dying. In fact, as soon as Mao died, the whole campaign collapsed, and his supporters were humiliated. Unhappily, many of the philosophers whose ideas were used in the campaign were also disgraced-with some, including Guan Feng, jailed for many years-and their innovative ideas on Confucius were promptly discarded and forgotten. Ironically, the piLin piKong movement of the early 1970s saw the greatest revival of Confucius's teaching in Chinese history. Every university, school, factory, commune, even kindergarten had to study The Analects as "negative material." One would have thought that the May Fourth movement had done such a good job of killing Confucius that he could be allowed to rest in peace. But this flogging of his corpse only had the effect of making Confucius spring back to life as soon as the beating was over. 
Before moving on from the Cultural Revolution period, I should highlight one other fundamental idea from The Analects that was singled out for relentless thrashing, because it relates to naming. In addition to "love ren" (人), another key definition of ren (仁) given by Confucius was the supremely backward-looking "self-restraint and returning to the rites." When asked to be more specific, Confucius proposed a "rectification of names" (正名) as a means of restoring order in society. He declared, for example, that rulers should behave like rulers, officials like officials, fathers like fathers, and sons like sons. He lamented that subordinates such as sons and officials were usurping the ways of their superiors, so that titles and names no longer held the meaning they had previously possessed (in the Zhou dynasty). Confucius certainly understood the importance attached to names.

The Cultural Revolution diehards also appreciated this and indeed sought to deconstruct traditional concepts to show that they were grounded in class. In other words, they sought to demonstrate that all of the righteoussounding Confucian moral principles actually favored the ruling classes. Typical of Cultural Revolution practice, names and titles were juxtaposed to comment on contemporary concerns. For the first time, Confucius was referred to by his name, Kong Qiu. Often, he was referred to as Kong Laoer (孔老二) (Kong Number 2), possibly because he was the second eldest among his siblings, but more probably because the movement was linked to Lin Biao, Mao's successor and Number 2 before he was purged. The term may also have referred to Zhou Enlai, who was at that time Number 2. Interestingly, in the vernacular, laoer also refers to the penis, so for the first time in history, Kong Qiu was called "Confucius the Prick." 6 In any case, the anti-Lin anti-Confucius campaign collapsed very quickly, and when Mao died, the vitriolic but engaging attacks on Confucius stopped, to be replaced by the search for positive essences in Chinese core values that are compatible with Marxism that were so familiar in the 1950s and that have resurfaced today. What is different today, however, is that advocates for Confucius argue that he was the precursor to many of the best in the West as well. Let us now look back to see how Confucius fared outside China after 1949.

6. I should mention that although most people in China would have picked up the vernacular meaning of laoer as "prick," this reading was never, to my knowledge, publicly acknowledged. 


\section{The Goings and Comings of a Diasporic Confucius}

After 1949, when Marxist-Leninist doctrine was the only avenue intellectuals in the mainland were able to explore, many influential Confucian scholars who disagreed with the new ideology simply packed up and left. Those who remained either tried, like Feng Youlan, to adapt Confucianism to the new ideology or stopped writing altogether. Liang Shuming and Xiong Shili were the two most significant philosophers to argue for decades for the revival of Confucianism in China. But their versions of Confucianism were heavily diluted by Buddhist elements, to the extent that Liang has been described as the "last Buddhist" as well as the "last Confucian." While Liang and Xiong are now considered the fathers of the New Confucianism school, there was simply no way for them to express their conservative ideas in the mainland after 1949. Their message that Confucianism and Chinese tradition held the key to a correct way of living in the modern world was carried out by their disciples, such as Mou Zongsan, Tang Junyi, and Xu Fuguan, who left China mainly for Hong Kong and Taiwan. Some became influential academics in universities and research institutes, such as Hong Kong University and Chinese University of Hong Kong, and many continued to develop the conservative Confucian teachings of their instructors in China by publishing scholarly articles. However, their writings had no impact in China and limited impact outside a very small circle of academic readers in Hong Kong and Taiwan.

The relative neglect of this group of scholars might have continued but for the Asian values debate that began around twenty years ago. In the 1980s, when some countries in East Asia experienced rapid economic growth, some tried to ascribe this economic "miracle" to Asian or Confucian values. ${ }^{8}$ Research in cultural differences in the social sciences has also projected Confucian values as a "dynamic dimension" in promoting economic growth. ${ }^{9}$ Philosophers were quick to join this chorus eulogizing the wonders of traditional ideas.

As part of this revival, a relatively obscure document published in

7. John J. Hanafin, "The 'Last Buddhist': The Philosophy of Liang Shuming," in New Confucianism: A Critical Examination, ed. John Makeham (New York: Palgrave MacMillan, 2003), 187-218.

8. Tu Wei-ming, ed., Confucian Traditions in East Asian Modernity: Moral Education and Economic Culture in Japan and the Four Mini-Dragons (Cambridge, Mass.: Harvard University Press, 1996), $x$.

9. Geert Hofstede, Cultures and Organizations: Software of the Mind (New York: McGrawHill, 1997), 164. 
1958 by Mou Zongsan, Xu Fuguan, Tang Junyi, and Zhang Junmai, titled "Declaration on Behalf of Chinese Culture Respectfully Announced to the People of the World," has been resuscitated as the beginnings of the formation of a new school of thought. ${ }^{10}$ This document is an "emotionally charged apologetic for traditional Chinese culture and the ethico-religious and spiritual values that the authors identify with that culture. . . [ [It] argues for the cross-cultural significance of Confucianism on the world stage." 11 As scholars who had fled China, the authors of the declaration believed that China was losing its cultural heritage. By 1958, they were also very aware that their versions of Chinese tradition were under siege and that Western, particularly American, ways of life were gaining ground. In their defense of Chinese culture, they also advocated the integration of the more positive aspects of Western culture, such as democracy and science, and they were keen to point out that traditional Chinese culture is compatible with liberal constitutional democracy. Their hope was that the world would see the merits of traditional Chinese culture as both compatible with and desirable in the modern world. In fact, they suggested that traditional Chinese ethics could act as a counterbalance to the materialistic greed and superficiality of modern culture.

Whatever its merits, this declaration is now acknowledged both within and outside China as the clarion call for the formation of the New Confucianism school. The writings of the main players of this new school have been published, and collections of their works have been widely distributed in China. While the content of their message might have related more specifically to traditional Chinese culture, the sentiments expressed in the document are echoed some three decades later by the advocates of Asian values, suggesting that, in Asia, at least, the wishes of the authors of the 1958 manifesto have come true. However, there is a basic difference between the situation then and now. The 1958 document was designed to combat the evils of Communism, which is why it incorporates Western values in its objectives. Its authors left China when it became Communist. Many New Confucians today, both within and outside China, by contrast, set out to prove that Confucius is good not only for Western democracy but also for a Communist state. This acceptance of a basically anti-Communist

10. For a good and relatively sympathetic review of the document, see Albert H. Y. Chen, "Is Confucianism Compatible with Liberal Constitutional Democracy?" Journal of Chinese Philosophy 34, no. 2 (June 2007): 195-216.

11. John Makeham, "The Retrospective Creation of New Confucianism," in New Confucianism, 28. 
statement shows the degree to which some Chinese are ready to prioritize nationalist imperatives over political correctness.

One of the clearest indications of the reversals in the treatment of the nation's philosophical heritage was the establishment of the Academy of Chinese Culture (Zhongguo wenhua shuyuan), headed by Tang Yijie, in 1985. Tang Yijie is one of the brightest and most influential historians of Chinese thought and has been a prolific writer on Chinese philosophy since the 1950s. ${ }^{12}$ In the late 1980s and early 1990s, at a time when "Asian values" were being advocated in East Asia, the academy was at the forefront of reevaluations of Chinese thought, particularly Confucianism. Part of its mission was to integrate research on Chinese culture in China and the West. Thus, scholars from outside China were invited to work and conduct research at the academy. One of these visiting scholars was Tu Wei-ming, a professor from Harvard University. Tu Wei-ming's participation in the explorations of Chinese values proved pivotal in the growth of new Confucianism outside China. Tu had written an influential article in which he indicated that essential Chinese culture was now more likely to be found outside than within China. The title of his thesis sums up its content most succinctly: "Cultural China: The Periphery as the Center." ${ }^{13}$

\section{A Man for All Seasons and All Peoples}

So there we have it. The best of Chinese culture, the essence of Confucianism, has now set up shop in the perceived center of world learning, Harvard. The periphery has indeed become the center. Confucianism is now considered so portable that a "Boston Confucianism" is said to have emerged, one that is admirably suited to American society. ${ }^{14}$ The inspirational thinker for this Boston Confucian school, Tu Wei-ming, is now the best-known of the New Confucians. He was also one of the major consultants for Lee Kuan Yew's failed attempt to institute traditional Confucian

12. Tang now claims he only "really" began to write on philosophy in 1980. He has negated all that he wrote before that time as political tracts and not philosophy as such. Tang Yijie, Ruxue shilun ji wai wupian [Ten commentaries on Confucianism] (Beijing: Beijing daxue chubanshe, 2009), 1 and 25.

13. Tu Wei-ming, "Cultural China: The Periphery as the Center," Daedalus 120, no. 2 (Spring 1991): 1-32.

14. Robert Cummings Neville, Boston Confucianism: Portable Tradition in the LateModern World (Albany: State University of New York Press, 2000). 
virtues in Singapore schools in the $1980 \mathrm{~s}^{15}$ and for a long time had a large following in China. ${ }^{16}$

The liberalization of academic inquiry is an admirable trend. Unfortunately, the "legacy" of the half century of Communist scholarship on Confucius is not only seen to have no academic merit; its methods and insights are also deliberately scorned and devalued. Thus, for example, class is hardly used as a tool for analysis, and when it is invoked, the method is scorned by influential scholars such as Jiang Qing.

Confucius might as well have been a running dog of the slave-owning class, because his teaching was elevated above class considerations. This is not surprising, because even when Maoism was a fad in some sections of Western academia in the 1960s and 1970s, studies of Confucius were mostly confined to philosophical theories and their relevance to contemporary life in the West. For the first time, Confucian scholars in both China and the West have now joined forces to show that Confucius's teachings are not only relevant in contemporary times but are also highly applicable in Western countries.

Today, when the "Made in China" label adorns every conceivable commodity in almost all corners of the globe, Chinese leaders feel the need for more than consumer goods to assure their citizens of their high moral status in the world. What better means to this end than schools that "sell" Chinese culture to the world? The Confucius Shop of May Fourth has been demolished, but the owners have simply packed up and opened Confucius Institutes instead. Housing a man for all seasons and all countries, the ubiquitous Confucius Institutes are therefore a part of the "soft power" offensive undertaken by the Chinese leadership to "charm" the rest of the world. Moreover, it also indirectly "repudiates Mao, since the Chairman had tried to wipe out the teaching of Confucian beliefs." 17

This essay is concerned specifically with the ideological effectiveness of naming and institutionalizing Confucius for political purposes. Will this work? Past experience has produced mixed results. The current attempt to institutionalize the Confucius icon is said to be not only modern but also

15. Eddie C. Y. Kuo, "Confucianism as Political Discourse in Singapore," in Confucian Traditions in East Asian Modernity, 304.

16. See, for example, the five-volume collection, Du Weiming, Du Weiming wenji (Wuhan: Wuhan chubanshe, 2002).

17. Joshua Kurlantzick, Charm Offensive: How China's Soft Power Is Transforming the World (New Haven, Conn.: Yale University Press, 2007), 68. 
global. I will show here that such a move is inherently self-contradictory. I accept that all societies contain contradictory values. Indeed, as Joseph Tamney observes in regard to Singapore, groups of people with contradictory values often coexist. And having contradictions within a civilization need not necessarily bring about the demise of that civilization. That said, the existence of fundamental inconsistencies within the one system can have unforeseen and harmful consequences, because "when these inconsistencies are built into public policies, political alienation increases, with the result that people detach from public institutions and concentrate on their own personal worlds." ${ }^{18}$ I should add that while efforts of the New Confucians to prove that Confucian ideology is good for modernity and internationalism are admirable, they have, perhaps inadvertently, succeeded in introducing contradictions into an already confused and unstable world. Political alienation has long plagued the Chinese system and it would be unfortunate to subject the world at large to this alienation when there are other viable operating systems. To illustrate my point, I will begin by examining how the New Confucians have presented their case.

\section{The Democratic Business Consultant}

The argument that Confucius is good for liberal democracy and international harmony stems mostly from the so-called Asian values debates of the 1980s and 1990s. Whether they were called Confucian values or "Asian values," these concepts, on the whole, represented a conservative politics with an emphasis on community rather than individuality, and status quo rather than change. This conservative stance was very convenient because, with the notable exception of Hong Kong, the governments of many states in the region were characterized by some Western commentators as repressive during the 1960 s and 1970s. To counter these allegations about their authoritarian or dictatorial nature, the leaders of these countries naturally encouraged and welcomed arguments that interpreted them as benevolently democratic, but with "Asian" or "Chinese" characteristics.

Had the Asian countries that espoused these values remained economically backward, their voices would not have been heard despite their desire to be depicted as democratic. However, by the 1970s and 1980s, some Asian countries in the east and southeast were becoming increas-

18. Joseph B. Tamney, The Struggle over Singapore's Soul: Western Modernization and Asian Culture (Berlin: Walter de Gruyter, 1995), 188. 
ingly wealthy. In particular, Japan was seen by some as posing a serious challenge to America as the Number 1 economic power. Leaders of some former European colonies, such as Singapore and Malaysia, eagerly sought to build a measure of national identity and self-confidence at the same time that they were laying claim to a new form of democracy. The most nagging aspect of the democracy debate to leaders who had come to power via the revolutionary route was the issue of human rights.

In 1993, a number of Asian representatives gathered in Bangkok to discuss the human rights issue. The statement that came out of the conference, the "Bangkok Declaration of Human Rights," upheld the universality of human rights. However, it also stated that it is important to take the particular cultures and histories of individual countries into consideration. The resulting implication that individual rights are predicated on social backgrounds suggested that human rights were relative rather than absolute. This gave rise to considerable discussion about what constituted these social backgrounds in the case of Asia. Many well-researched and thoughtful essays on the topic appeared during the 1990s, culminating in books such as Human Rights and Asian Values ${ }^{19}$ and The East Asian Challenge for Human Rights. ${ }^{20}$ Most contributors agreed that values such as communitarianism were important for national identity formation, and that they were not specific to any culture. While the universality of human rights was more or less supported, some argued for the need to allow for areas of justifiable moral differences between societies. As a result of these concerns, many East Asian scholars looked for evidence of compatibility between Confucianism and Western-style liberal democracy, in the same way that Feng Youlan and his supporters had tried to prove that Communism and Chinese tradition were compatible in China in the 1950s and 1960s. ${ }^{21}$

This was particularly true of Chinese scholars. At the same time as diasporic Chinese New Confucians were reviving the spirit of the 1958 manifesto, well-respected, nonethnic Chinese Sinologists also tried to prove that Asian values and Confucianism were consistent with human rights. As Wm. Theodore de Bary argued in a speech in front of the Chinese

19. Michael Jacobsen and Ole Bruun, eds., Human Rights and Asian Values: Contesting National Identities and Cultural Representations in Asia (Richmond, UK: Curzon Press, 2000).

20. Joanne R. Bauer and Daniel A. Bell, eds., The East Asian Challenge for Human Rights (Cambridge: Cambridge University Press, 1999).

21. Sor-hoon Tan, Confucian Democracy: A Deweyan Reconstruction (Albany: State University of New York Press, 2003). 
political leadership in 1994, Confucius and his followers, such as Mencius, expressed concern about the issues of the day. De Bary proposed that a series of conferences should be held to explore issues such as human rights to see how they were situated in Chinese and Western cultures. By claiming that the communitarianism of Confucianism was, in its time, compatible with human rights, even human rights as understood in contemporary America, de Bary attempted to modernize Confucianism for a Western audience. True to his word, a series of conferences on Confucianism and human rights were held, under the encouragement and direction of de Bary, who also delivered a series of lectures that were later collected in the volume Asian Values and Human Rights: A Confucian Communitarian Perspective. ${ }^{22}$ As we have seen in the reinterpretations of Confucius in China itself, what are seen as Confucian values are so malleable that any system could incorporate such ideas. Indeed, based on the premise that each country has its own individual conditions, neoconservatives in China such as Jiang Qing swayed many with their contention that Confucianism is more suitable than liberal democracy for China. ${ }^{23}$

The idea that Confucianism stood for communitarianism and harmony, and that these values are not incompatible with either democracy or Communism and could therefore be useful in both democratic and socialist states might not sound completely ludicrous. However, in the 1980s and 1990s, when East Asia and China began to take pride in their ability to create wealth, Confucius also became an emerging entrepreneur. Given the fact that Confucianism had for centuries been accepted as a philosophy that was hostile to commerce and monetary concerns (indeed, China's scholar class has a lengthy and well-documented disdain for commerce), it seems inconceivable that Confucius could be portrayed as a philosopher who taught people how to make money. The trend to cast Confucius as a business consultant was based on changing priorities in East Asia, especially China. After years of seeing itself as leading the world in revolutionary correctness, China, under Deng Xiaoping, wanted to catch up economically with Western countries as quickly as possible. By 1984, when the Interna-

22. Wm. Theodore de Bary, Asian Values and Human Rights: A Confucian Communitarian Perspective (Cambridge, Mass.: Harvard University Press, 1998).

23. See, for example, Jiang Qing, Shengming xinyang yu wangdao zhengzhi [Faith in life and kingly politics] (Taipei: Yangzhengtang wenhua shiye gufen youxiangongsi, 2004). John Makeham provides a good summary of the basis of Jiang's ideas and his impact in his Lost Soul: "Confucianism" in Contemporary Chinese Academic Discourse (Cambridge, Mass.: Harvard University Asia Center for the Harvard-Yenching Institute, 2008), 261-76. 
tional Confucian Association was established in Beijing, Lee Kuan Yew, that ardent advocate of Asian values, was elected honorary director. Lee Kuan Yew's role in the association was a clear signal that Confucianism was seen as an important ingredient for building a modern, prosperous society. Since that time, there have been numerous international conferences to commemorate Confucius, and most foreign participants in these conferences have come from East and Southeast Asia.

By the 1990s, the new Confucian message was being forcefully promoted. From a sagely adviser to kings and statesmen everywhere, Confucius had been turned into a management consultant whose words set the benchmark for good business practice. ${ }^{24}$ Very quickly, comparative studies of cultures in the social sciences also projected Confucian values as a "dynamic dimension" in promoting economic growth. ${ }^{25}$ And in China, scholars who for many years had called for the "inheritance" of Confucius's educational thought were understandably quick to cash in on the economic boom in East Asia. Confucius's morals are considered exemplary because they are said to promote production and profit. However, as indicated earlier, Confucius had always been understood to be above monetary motives. The Analects unambiguously states that "the gentleman (junzi) understands the importance of morality $(y i)$ and the inferior man (xiaoren) understands the importance of profitability (li)." ${ }^{26}$ In the context of the Spring and Autumn Period and the Warring States Period, this is an important pronouncement. The greatest challenge to Confucians at that time was Mozi, who unashamedly advocated profit and utility as desirable goals. Confucians throughout the ages were considered to have placed morality above profits and utility, whereas the Mohists took the opposite stance. The Confucian hatred for the utilitarian profit motive (though some would argue that the Confucians were more against using immoral means to accumulate profit rather than profit per se) continued into the twentieth century, with merchants and business people theoretically relegated to almost the lowest social status in Chinese society.

Articles that discuss the relationship between ethics and utility usually conclude by arguing the need for some degree of morality in an

24. In Europe, a similar transformation took place within Protestantism at the beginning of the Industrial Revolution, indicating that such changes may be symptomatic of a more general capitalist modernity.

25. Hofstede, Cultures and Organizations, 164.

26. Yang Bojun, Lunyu yizhu [The Analects translated and annotated] (Beijing: Zhonghua shuju, 1958), 42. 
age when "money is all." ${ }^{27}$ In quick succession, scholars sought to demonstrate the connection between Confucius's views on the profit motive and the modernization of China, claiming that the notions of both righteousness (yi) and profit (li) were important in this age of rapid economic growth. ${ }^{28}$ Kuang Yaming, former president of Nanjing University and a staunch Communist, contended in an influential paper that, on close examination, Confucius did not really stress righteousness above profit. In fact, his highest ideal was "the Great Commonwealth," in which righteousness and profit were in harmony and in unity. ${ }^{29}$ The reason Confucius highlighted the conflict between righteousness and profit was that he realized that "the Great Commonwealth" was difficult to accomplish in his time. He had thus emphasized righteousness so that an ethical society could at least develop before the Great Commonwealth could be realized.

Such reasoning was common throughout the 1980s and 1990s, when there was a concerted effort to show that Confucian ideas were favorable to economic growth. In addition to many articles devoted to the relationship between Confucian ethics and business management, a number of conferences were held to examine traditional Chinese morality and the market economy.$^{30}$ Using the generally accepted view that the essential core of Confucius's teaching is benevolence (ren), and that ren meant the discovery of humanity in human relationships, scholars sought to demonstrate that this emphasis on the centrality of the human was the essential element that had been missing in modern management. ${ }^{31}$ This is certainly difficult to reconcile with the Cultural Revolution interpretation of ren as loving slave owners and dictating to the common people. Furthermore, it is often argued that there is a close connection between Confucian and socialist economic morality, whereby in a developing socialist market economy, Confucian ethics should be used to combat the corrupting influence

27. Zang Hong, "Lüelun rujia de yili guan" [On the Confucians' attitude towards Yi-Li], Xuexi yuekan [Study monthly] 4 (1986): 21.

28. Miao Runtian, "Qianlun Konzi de yili guan ji qi xiandai yiyi” [On Confucius's attitude towards Yi-Li and its modern significance], Qilu xuekan [Qilu journal] 1 (1989): 55-59.

29. Cited in Song Zhongfu, Zhao Jihui, and Pei Dayang, Ruxue zai xiandai Zhongguo [Confucianism in modern China] (Zhengzhou: Zhongzhou guji chubanshe, 1991), 358-59. 30. Hu Dongyuan, "Zhongguo chuantong wenhua, shichang jingji, daode jianshe" [Traditional Chinese culture, the market economy, moral development], Xuehai [Sea of learning] 1 (1996): 52-54.

31. See, for example, Ye Ruixin, "Kongzi de yili guan" [Confucius's attitudes towards Yi-Li], Shanxi daxue xuebao [Shanxi University journal] 4 (1998): 33-37. 
of the lust for money ${ }^{32}$ This view was even more appealing because of the belief that first the Cultural Revolution and then modernity had a dehumanizing and alienating effect on people, especially the young. ${ }^{33}$

Confucius is therefore celebrated as the sage who outlined a way for management to be carried out efficiently by humane cadres and factory managers. In a very detailed article, Peking University economist Zhao Jing argues that Confucius's management techniques could be adopted by capitalist and modern enterprises. The thrust of his argument targets "leaders" in both industry and politics. In particular, he claims that those who emphasized politics a few years ago "did not understand our national character" and wanted to rush ahead with Communism without checking whether it was a realistic move or not. ${ }^{34}$ The national character he refers to, of course, was based on Confucianism. Zhao acknowledges that Confucius's lack of attention to the economic structure of nations had a negative impact on China. However, he believes that if Japan and Korea were able to modernize by adopting Confucius's management techniques, China should also be able to do so. "Moral management" became the motto under which many writers advocated the return of Confucius in the new industrial China. ${ }^{35}$

\section{The Teacher, the Feminist, and the Good Life Guru}

While politics and economics have been the major concerns of the Chinese leadership, the institutionalizing of Confucius in education is also seen as essential in the new era. I began with the rapid expansion of the Confucius Institutes, so I should say a few words here about how Confucius's name has been used in the educational field. Through success in education, the Chinese literati of the past and the scholar-gentry of modern

32. Liu Minghua, "Rujia yili guan yu fazhan shehuizhuyi shichang jingji" [On the Confucians' attitudes toward Yi-Li and the developing socialist market economy], Guizhou daxue xuebao [Guizhou University journal] 1 (1996): 29.

33. Song Xiren, "Rujia chuantong yili guan yu qingshaonian daode jiaoyu" [On the Confucians' attitudes toward Yi-Li and the moral education of the young], Jiangsu shehui kexue [Jiangsu social sciences] 6 (1993): 119-23.

34. Zhao Jing, "Kongzi de guanli sixiang he xiandai jingying guanli" [Confucius's management ideas and modern administration and management], Kongzi yanjiu [Confucius research] 1 (1989): 34.

35. Xu Qixian, "Lun rujia lunli yu daode guanli" [On Confucian ethics and moral management], Zhongguo renmin daxue xuebao [Chinese People's University journal] 1 (1998): 48-54. 
times have been able to acquire a sense of meaning and power in society. In the post-Mao period, debates on education took on an urgent tone. Like teachers everywhere, many educators saw themselves as the guardians of social morality. Conservative educators in particular argued that there was a moral vacuum after the disillusionment arising from the Cultural Revolution and that Confucian moral education was a means of filling this gap.

By the early 1990s, Confucius and Mao Zedong were seen as the two greatest educators in Chinese history-one ancient, one modern. In an interesting article on this topic, Xu Quanxing, a member of the CCP Central Committee Party School, argues that Mao Zedong had, on numerous occasions, sought to be remembered as a teacher. One of the most interesting quotations from Mao Zedong is his assessment of Confucius, given in a talk in 1938. After eulogizing Confucius, Mao asks rhetorically, "Why didn't Confucius become a Communist? That's because the masses those days did not want him to be a Communist; they wanted him to be a teacher. But today, the masses want us to be Communists." ${ }^{36}$ In other words, if Confucius had been alive in the 1930s, he would have been a Communist leader. Such claims are almost clichés; what is remarkable about this one is the manner in which it is used to help argue the paramount importance of the ancient sage for Chinese culture.

Party theorists such as Xu Quanxing are not merely debating the merits of Confucian education. As a professor of the Communist Party School, Xu leaves little doubt about the political motivation behind his article. He concludes with a short comment to the effect that although Confucius's influence on Mao Zedong was generally positive, it also had a negative aspect. The greatest shortcoming in Confucius's educational thought, according to Xu Quanxing, is his "emphasis on ethics and disregard for materiality." ${ }^{37}$ Because of this, Chinese thinkers throughout the ages had paid insufficient attention to material and economic progress, which explains why Mao Zedong was partial to political education and neglected modernization and economic production. Xu Quanxing claimed that Deng Xiaoping rectified this bias in Mao Zedong by emphasizing the importance of education in achieving modernization and attaining the highest international standards. ${ }^{38}$

36. Xu Quanxing, “Kongzi yu Mao Zedong: Gujin weida 'jiaoyuan'” [Confucius and Mao Zedong: Great "teachers" of the past and present], Kongzi yanjiu [Confucius research] 4 (1993): 4.

37. Xu Quanxing, "Kongzi yu Mao Zedong," 6.

38. Xu Quanxing, "Kongzi yu Mao Zedong," 6. 
There is thus more concern about education and internationalization. And indeed, the New Confucians outside China have also written a great deal about the merits of Confucian education for peace and harmony in the world. Although this is not made explicit, the main purpose of the Confucius Institutes is to promote Chinese language and culture in Western society. There is a strong belief that moral superiority follows economic might, and that because China is seen as economically successful, the cultural aspects of Chinese society should also have an international impact, and Confucianism should be internationalized.

Gender is one of these cultural aspects. During the last century, when the position of Chinese women became a popular topic among intellectual circles, it was taken for granted that Confucianism, no matter how benevolent, was ultimately patriarchal. In The Analects itself, the detested "inferior people," the xiaoren, are mentioned twenty-four times, mostly as a counter to the gentlemen, the junzi. But in keeping with the disregard for women in Confucius's time, there is no reference to women as a group. Notably, the only time women are mentioned is when Confucius associates them with the xiaoren, the mean and inferior people he detested. ${ }^{39}$ One would think that this dearth of instruction regarding women would confirm the traditional understanding of Confucius as a misogynist. But just as it is argued that Confucian ethics are communitarian and therefore more humane and appropriate to a democratic state and bureaucracy, the fact that Confucius had so little to say about women has simply left a lot of room for extravagant interpretations. Some have even tried to argue, as recently as a few years ago, "that the teachings of Confucius are similar to those of some Feminists"! The justification for such outrageous assertions usually rests on the argument that Confucius advocated the notion of ren (仁). In its written form, ren is "composed of two parts, the figure of a person and the numeral two, and so we render it into English as 'person to person care' or just 'care' to be brief." 40 In this instance, the authors are targeting a Western audience, which is presumably in favor of Chinese culture but not its sexist tendencies, so Confucius is presented as a caring, loving man.

This claim was made in a Taiwanese popular magazine targeted at a Western nonspecialist audience. Notwithstanding the fact that pairing feminism with care ethics again places women in the babysitter rather than controller role, many well-meaning scholars elaborated on Confucius's

39. Yang Bojun, Lunyu yizhu, 198.

40. James D. Sellmann and Sharon Rowe, "The Feminine in Confucius," Asian Culture 26, no. 3 (1998): 4. 
alleged feminist credentials. As early as 1994, highly respected philosophers were defending the thesis that Confucius was misunderstood and that his people-centered philosophy demonstrated that his views were not antiwomen. Confucianism appeared to be sexist only because of distortions introduced after the Han dynasty. ${ }^{41}$ The idea that Confucianism was beneficial in promoting modern gender relations was taken up by many other Western academics, such as Henry Rosemont, who appears to consider Confucianism less competitive and individualistic, and therefore less masculine, than Western practices, and who believes that the two modes of thinking could be mutually beneficial. ${ }^{42}$ By carefully explaining that care ethics relate to "care" that is beyond blood relationships, and that Confucian ethics are based on human relations such as filial obligations that are never reciprocal, other commentators unapologetically explode the notion that the classical Confucians could complement modern-day care ethics. ${ }^{43}$

Some of the above claims are similar to the New Age appropriation of ancient philosophies as a path to self-fulfillment and happiness. This is precisely what one woman academic has managed to successfully achieve in China. In the last few years, Yu Dan, a media studies professor at Beijing Normal University, has become an academic celebrity because of her television appearances and books on Confucius and Zhuangzi. The fact that she has sold tens of millions of copies of her books on Confucius and Zhuangzi, is the subject of many books and articles, is a familiar face on television, and has a large Internet blog following all ensure that her version of Confucius is kept alive and popular. She summarizes her argument on the cover of her most important book, Confucius from the Heart, claiming, "The truths that Confucius gives us ... tell us all how we can live the kind of happy life that our spirit needs." ${ }^{4}$

41. Chenyang Li, "The Confucian Concept of Jen and the Feminist Ethics of Care," later republished in The Sage and the Second Sex: Confucianism, Ethics, and Gender, ed. Chenyang Li (Chicago: Open Court, 2000), 23-42. This book contains ten scholarly papers on Confucianism and women.

42. Henry Rosemont Jr., "Classical Confucian and Contemporary Feminist Perspectives on the Self: Some Parallels and Their Implications," in Culture and Self: Philosophical and Religious, East and West, ed. Douglas Allen (Boulder, Colo.: Westview Press, 1997), 63-82.

43. Ranjoo Seodu Herr, "Is Confucianism Compatible with Care Ethics? A Critique," Philosophy East and West 53, no. 4 (October 2003): 471-88.

44. Yu Dan, "Lunyu" xinde [Reflections on The Analects] (Beijing: Zhonghua shuju, 2006). An English translation has appeared as Confucius from the Heart: Ancient Wisdom for Today's World, trans. Esther Tyldesley (London: Macmillan, 2009), 10. 
In a highly materialistic and consumerist China where many are searching for but not finding inner peace, this understanding of a major classical text as a vehicle for achieving a happy or good life has been embraced by millions. Yu Dan's popularity and celebrity status have continued to gain momentum, especially because, despite being a university lecturer, she does not try to analyze The Analects in academic detail but only refers to specific passages. She also uses personal anecdotes to show how the ideas behind the classic can be intuitively helpful for a modern society. But she has also been attacked, sometimes quite vehemently, especially by other aspiring young scholars. ${ }^{45}$

Yu Dan has been extensively covered in respected Western newspapers, including the International Herald Tribune and Los Angeles Times, as well as Western scholarly commentaries. Daniel Bell, for example, points out that Yu Dan has made use of Daoism (and Western liberal ideas) to urge people to look inward rather than change society, and that this in effect depoliticizes The Analects, which Bell considers to be about political action and commitment. He claims that Yu Dan's account is "complacent, conservative, and supportive of the status quo." ${ }^{46}$ Bell is right to point out that by encouraging people to look into themselves and selectively quoting from The Analects to seek the good life, Yu Dan is encouraging apathy. To me, her philosophy is similar to that embodied by Lu Xun's character Ah $\mathrm{Q}$, whose capacity for self-delusion enables him to brag about his importance and be complacent about his miserable existence despite occupying the status of a village idiot. Interestingly, some fifty years ago, Guan Feng accused Feng Youlan and other New Confucians of behaving like a modernday Ah $\mathrm{Q}$. They were vilified for trying to use the classical philosophers to avoid engaging in the political transformations occurring in the New China. ${ }^{47}$

\section{Institutionalizing a Postmodern Confucius}

Since the advent of modernity in China, Confucius has taken on a postmodern persona. He can be anything anyone wants him to be. Early

45. See, for example, the ten essays by $\mathrm{PhD}$ candidates collected in $\mathrm{Xu}$ Jinru and Yang Haoou, eds., Jie "du" Yu Dan: Shi bo shi vs Yu Dan [Disinfecting Yu Dan: Ten PhD's vs. Yu Dan] (Beijing: Zhongguo wuzi chubanshe, 2007).

46. Daniel A. Bell, China's New Confucianism: Politics and Everyday Life in a Changing Society (Princeton, N.J.: Princeton University Press, 2008), 174.

47. See Kam Louie, Inheriting Tradition: Interpretations of the Classical Philosophers in Communist China, 1949-1966 (Hong Kong: Oxford University Press, 1986), 125-28. 
reformers in the Qing dynasty tried to assert the superiority of Chinese culture by claiming that Confucius and other classical Chinese philosophers provided the inspiration for Jesus Christ's scientific outlook! Thus, early modernizers such as Wei Yuan and Xue Fucheng made the outrageous claims that Jesus had access to the Confucian classics and had learned from Mozi, thus giving Western civilization a head start in science..$^{48}$ But by the May Fourth period, iconoclasts such as Chen Duxiu and Lu Xun saw Confucius as a reactionary who, along with his shop, should be toppled and smashed. More recently, during the Cultural Revolution, the radicals were almost hysterical in their denunciation of him as a running dog of all sorts of ghosts and demons. Everyone claimed to know the real Confucius, but for more than a hundred years no one has been able to pin down this chameleon. Indeed, in these postmodern times, some scholars in the West wonder if Confucius was really responsible for The Analects or whether, in fact, he himself may have been "manufactured" by later generations. ${ }^{49}$

So what can explain this new attempt by both the Chinese government and Chinese academics within and outside China to appropriate and eulogize Confucius? Why, in the naming of the Confucius Institutes, institutionalize him for world consumption? At a time when American culture seems to dominate the world and there is widespread concern about American unilateralism, it may be natural for nations to try to avoid being swept along in the American tide by inventing their own national identity. But is it wise for China to use Confucius as a "brand name" to reach out to the world? ${ }^{50}$ Some have raised doubts about whether the Chinese government has really established the Confucius Institutes to promote international understanding and harmony. I am not interested in that question. All governments have the right, indeed the duty, to try to "charm" others with their cultural software.

But I do question the choice of the name. There is an implicit belief among most people that because Confucianism has long dominated Chi-

48. See Jerome Chên, China and the West: Society and Culture, 1815-1937 (London: Hutchinson, 1979), 65-68.

49. See E. Bruce Brooks and A. Taeko Brooks, The Original Analects: Sayings of Confucius and His Successors (New York: Columbia University Press, 1998); and Lionel M. Jensen, Manufacturing Confucianism: Chinese Traditions and Universal Civilization (Durham, N.C.: Duke University Press, 1997).

50. Xin Ming, "Shijiexing de 'Zhongguo re' tsuisheng le Kongzi xueyuan" [The international "China fever" gave birth to the Confucius Institutes], Sixiang zhengzhike jiaoxue [Teaching of ideological and political curricula] 9 (2007): 88. 
nese culture and because Confucius is a Chinese name, we should adopt it to represent China. But that's like proposing changing the Voice of America to the Voice of Jesus. Most Americans may identify themselves as Christians, but America is much more interesting and diverse than one dominant religion or one individual. In the same way, an institute that purports to promote Chinese culture should not do so in the name of one person, especially if that name or person has generated bitter controversies in the recent past. Like many other overarching philosophies and beliefs, Confucianism is fraught with inconsistencies. And even though some academics have tried to argue that Confucianism is compatible with and possibly superior to Western democracy, modern feminism, and best business practices, the truth is that the basic tenets of Confucian thinking are found in conservative people everywhere. For example, the cherished Confucian notions of family values and filial piety can be found in most cultures. And politically, Confucius's "rectification of names" and "return to the rites" are, in general, directives for social regression.

Confucius lived during a time of great social upheaval, when many warring states fought endless battles with each other until the establishment of the Qin dynasty. And we are currently also witnessing a world in conflict, so that notions such as a "clash of civilizations" have recently gained currency. ${ }^{51}$ It is perhaps understandable that newly emerging countries such as Singapore deem it necessary to fabricate some concept of Asian values as a counterbalancing force to what they perceive as the corruptive influence of Western values. The need to assert one's own identity in the face of the overwhelming impact of American might is understandable and perhaps legitimate. However, Chinese culture has been around for a long time, and unlike many other small and endangered cultures that are being overwhelmed by hegemonic civilizations, it is likely to be around for a long time to come.

Those elements of Chinese culture that are relevant to the contemporary world will survive regardless of the babbling of academics. It is somewhat pathetic to promote them in such crass ways, especially when the elements of Chinese culture that are being promoted are so antiquated. However we look at it, Confucianism is a conservative philosophy. Distilling and mixing Confucian ideas until we find an "essence" that fits suspect national agendas, such as the naming of the Confucius Institutes, is not Asian Responses, ed. Salim Rashid (Dhaka, Bangladesh: University Press Ltd., 1997). 
a sound approach. If we must revive and defend Chinese traditions, we should at least salvage those useful elements that might have been traditionally neglected but that are more suited to today's world. Any political leadership today would be unlikely to promote the Daoist wuwei (nonaction) as a model, and the Gang of Four's spectacular failed attempts at salvaging the Legalists proves that Legalism is now also a lost cause.

However, there are other significant traditions that warrant consideration. For example, Mohism, with its pacifist and scientific bent, seems to me to be worthy of revival. So why not go for Mozi? He stood for universal love rather than family loyalty, and utilitarianism and profit rather than lofty words and morals. His ethics and scientific spirit seem to suit the modern world better than other traditional Chinese philosophies. Yet, throughout Chinese history, including the Communist period, when China should have "inherited" him, Mozi has largely been neglected. ${ }^{52}$ If we do not choose to walk out of the shadow of Confucius now, we may once again miss an opportunity to change how Chinese culture is regarded around the world.

At a time when international relations are changing rapidly, and China is poised to play a much more significant role, Chinese culture will inevitably have a major global impact. While Communism remains the dominant ideology in China and the Communist leadership is unlikely to abandon this philosophical and political system in the foreseeable future, it is also very unlikely that the current rulers would want to preach the merits of Communism to the rest of the world. They have, in fact, fallen back on the other ideology they know: Confucianism. For them, Confucianism was a powerful cohesive force in imperial China, and it could be used as an ideology to build a harmonious society now. However, the Confucius icon has been an extremely controversial one in modern China, and Confucianism has been a divisive ideology in the last century. Furthermore, as I have demonstrated above, the confusion surrounding the debates on how to salvage tradition in a new China have been compounded by incoherent interpretations of Confucius's teachings in recent years. All the indicators suggest that domestically, the advocacy of Confucianism will in practice lead to the promotion of very conservative and inconsistent values. Internationally, if such values are to be paraded as the best of "Chinese" essences, China's contribution to world culture will be a confused and regressive one. 